\title{
Oak growth in Midwestern North America linked with post glacial climate epochs in the North Atlantic
}

\author{
Richard P. Guyette ${ }^{1}$, Michael C. Stambaugh ${ }^{1}$, Anthony Lupo ${ }^{1}$, Rose-Marie Muzika ${ }^{1}$ and Daniel C. Dey ${ }^{2}$ \\ 'School of Natural Resources, University of Missouri, Columbia, USA; guyetter@missouri.edu \\ ${ }^{2}$ North Central Research Station, U.S. Forest Service, Columbia, USA; ddey@fs.fed.us
}

Early Holocene tree-ring climate proxy development from sub-fossil oak wood (buried wood not mineralized) has been limited to Europe. Sub-fossil oak that has been collected from the rivers of Missouri and lowa is abundant, well preserved, and has been determined to be at least $13.82 \mathrm{cal}$ ka BP in age. This ancient oak wood represents riparian forest trees (Quercus bicolor Mich. and Quercus macrocarpa Mich.) that have been recruited into sediments by flooding and the erosion of stream banks. Large and heavy oak trees become buried rapidly by stream sediments and are then stored in the broad floodplains of these low-gradient streams for thousands of years. Although recruitment, reburial, excavation, and movement of wood is common, the relatively short length of these streams ensures that sampled oak is rarely, if ever, more than $50 \mathrm{~km}$ from where it originally grew, thus, spatially defining the climate region of origin. About 7 ancient oak trees ( $>500$ yrs BP) are found per $\mathrm{km}$ of stream reach that have a sufficient number of rings (90 to over 280) for use in the construction of tree-ring chronologies. The ${ }^{14} \mathrm{C}$ and tree-ring dating of the 230 oak trees collected to date indicate that the average tree grew about 2000 years ago.

One of several ongoing projects utilizing ancient oak wood is the documentation of growth and climate during the last post glacial climate epoch, in what is now part of the mid-continental North American agricultural region. One of our goals is to link well-documented climate change in maritime environments with the continental climate of what are now important agricultural regions. For example, the Younger Dryas event has been documented in the North Atlantic and Europe as a period of time marked by abrupt climate change and cooling (Alley, 2000). Here, we provide tree-ring

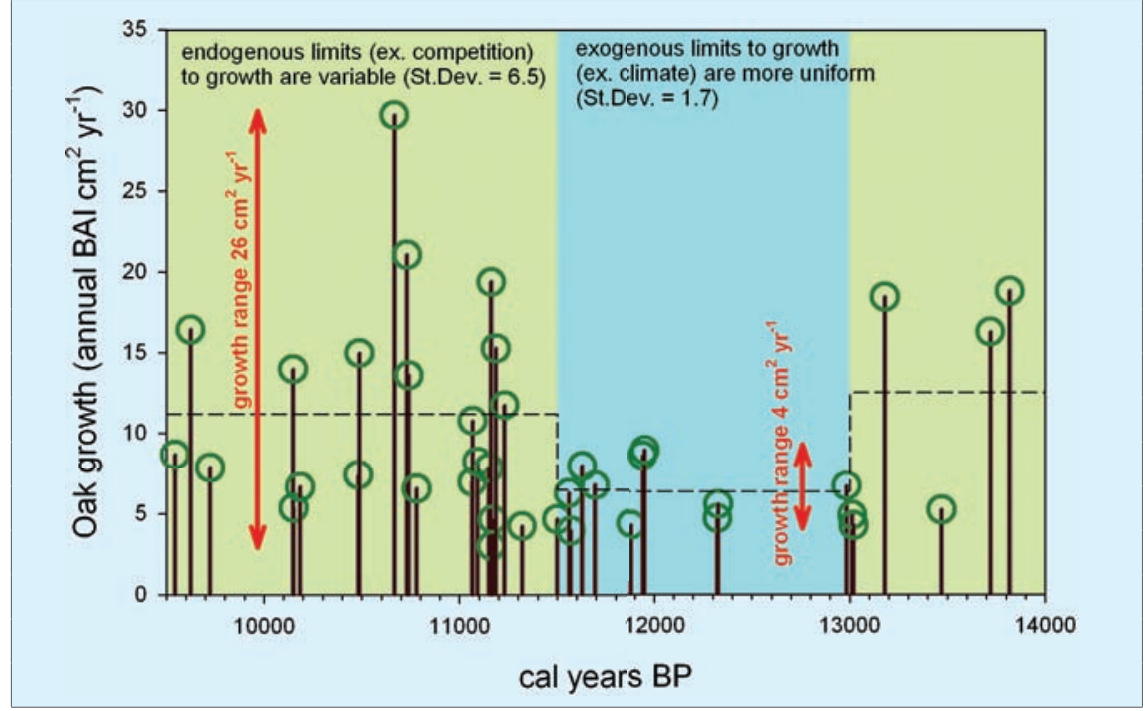

Figure 1: Oak growth (BAl - basal area increment) in mid-continental North America $193^{\circ} 20^{\prime}$ $W, 40^{\circ} 10^{\prime} N$ ) during the glacial-Holocene transition. Mean annual BAl of individual oak trees shows significantly (probability $p<0.01$ ) reduced growth and variance during the Younger Dryas (blue band). Dashed line: mean BAl before, during and after the Younger Dryas. Red arrows: hypothesized range in growth between tree populations limited by endogenous factors (competition) and exogenous factors (climate).

and isotopic evidence that growth and climate change were synchronous between the North Atlantic and mid-continental North American sites that lie $12,000 \mathrm{~km}$ to the southwest.

Oaks that were dated between 9.5 and 14 cal ka BP using ${ }^{14} \mathrm{C}$ and density dating (Guyette and Stambaugh, 2003) showed decreased growth (Fig. 1) and depleted $\delta^{13} \mathrm{C}$ (Fig. 2) coincident with North Atlantic climate proxies. The mean annual basal area increment (BAI; an area-based metric of tree stems) of oak trees was significantly ( $p$ $<0.01)$ less $\left(6.5 \mathrm{~cm}^{2} / \mathrm{yr}\right)$ during the Younger Dryas (Fig. 1) compared to growth during the rest of the post glacial climate period $\left(11.2 \mathrm{~cm}^{2} / \mathrm{yr}\right)$. Mean maximum annual BAI (17.0 $\mathrm{cm}^{2} / \mathrm{yr}$ ) was reduced by $54 \%$ during the Younger Dryas. Between-tree growth variance in BAl was about $75 \%$ less during the Younger Dryas than during the whole post glacial period (9.5-11.5 and 13-14 cal ka BP). A decrease in the variance of growth rates within a tree population would be expected if limits on growth switched from highly vari- able endogenous factors (forest competition) to regional exogenous factors (climate). Five-point moving averages of the mean ring width of the oak trees and temporally paired $\delta^{18} \mathrm{O}$ values (Fig. 2) from Greenland ice (GISP2) were correlated ( $r=$ 0.57) during the post glacial climate period. Whole tree mean ring width was significantly ( $p<0.01$ ) reduced during the Younger Dryas compared to adjacent post glacial climates. In addition to growth evidence, the low abundance of oaks in the early part of the Younger Dryas suggests a climate that was limiting to oak reproduction. The longest temporal gap between sample dates in the 14,000-year-record occurs during the first part of the Younger Dryas ca. 12.48 to 12.99 cal ka BP, and coincides with gaps in the European record (Friedrich et al., 2004). This suggests unfavorable conditions may have existed for regeneration and growth of trees across both continents during the first half of the Younger Dryas.

Values of $\delta^{13} \mathrm{C}$ (Fig. 2) in oak wood are found to be positively and significantly correlated $(r=0.74)$ 


\section{Science Highlights: U.S. ESH Program}

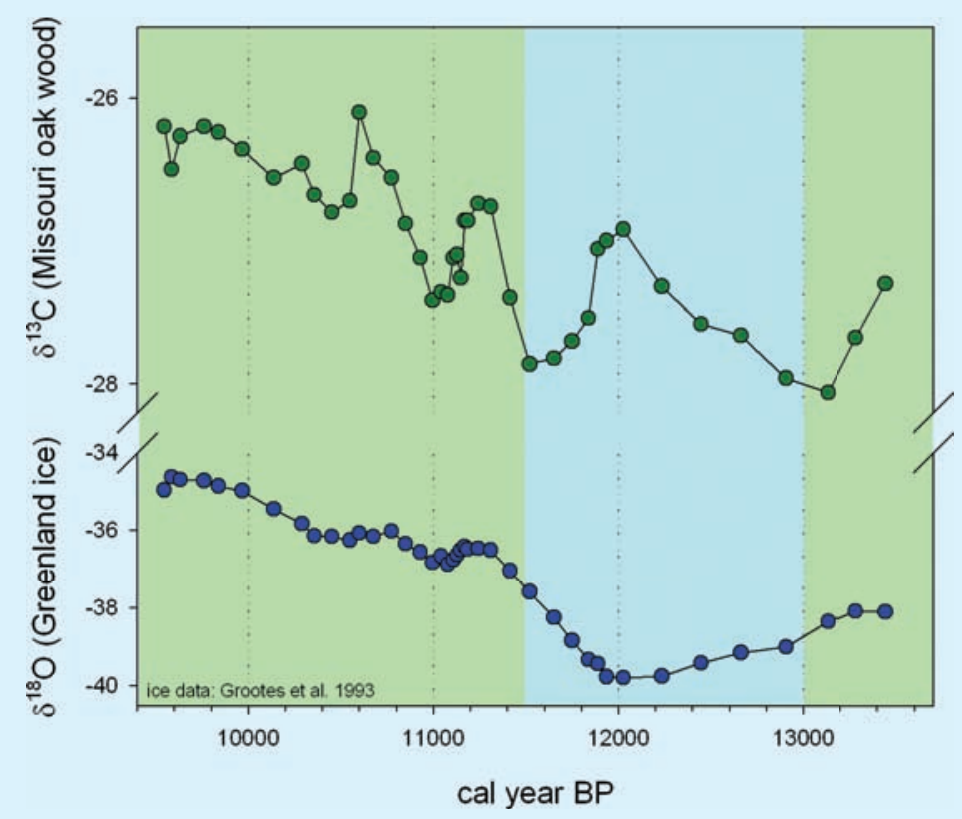

Figure 2: Stable isotope data for oak $\left(\mathrm{d}^{13} \mathrm{C}\right)$ in mid-continental North America $\left(93^{\circ} 20^{\prime} \mathrm{W}, 40^{\circ} 10^{\prime} \mathrm{N}\right)$ paired with $\delta^{18} \mathrm{O}$ from Greenland ice (GRIP and GISP2 data, Grootes et al., 1993). Paired values of $\delta^{13} \mathrm{C}$ and $\delta^{18} \mathrm{O}$ infer a climate link during the post glacial-Holocene transition between maritime climate of the North Atlantic and continental climate of Midwestern North America.

with temporally paired $\delta^{18} \mathrm{O}$ values (GRIP, GISP2) during the post glacial period. This association occurs despite the complexities of possible ${ }^{13} \mathrm{C}$ signals in tree rings (Loader et al., 2003). The termination of the Younger Dryas (about 11.5 cal ka BP) in mid-continental North America oak is marked by an expected and abrupt enrichment in the climatesensitive stable isotope $\delta^{13} \mathrm{C}$. This abrupt termination is synchronous with dates ofYounger Dryas termination based on pollen, ice core and tree-ring studies from marine and maritime regions of the North
Atlantic. Additionally, an increase in oak $\delta^{13} \mathrm{C}$ ca. 12.0 cal ka BP is coincident with intra Younger Dryas variability, as documented by $\delta^{18} \mathrm{O}$ from Greenland ice cores (Grootes et al., 1993). Increasing $\delta^{13} \mathrm{C}$ in oak during the postYounger Dryas transition to the Holocene is found to be consistent $(r=0.64)$ with changes in Greenland $\delta^{18} \mathrm{O}$ (GISP2).

Our preliminary results indicate that despite the low resolution of our data, climate change during the glacial-Holocene transition in midcontinental North America was approximately synchronous with that in the North Atlantic $(\sim 4,500 \mathrm{~km}$ northeast of the study site). In addition, serial correlation among tree growth and isotope chronologies suggests that post glacial climate variations had marked effects on the growth rates of trees. The construction of tree-ring chronologies for the Younger Dryas will eventually provide an annual-resolution climate proxy for an under-represented continental region.

\section{Note}

Radiocarbon dates are on file at commercial laboratories (Beta Analytic Inc. Miami, FL) as well as the Missouri Tree Ring Laboratory (http://www.missouri.edu/ guyetter/) where the growth data is also stored. Future ${ }^{14} \mathrm{C}$ dated 'floating' ring-width chronologies will be posted at International Tree-Ring Data Bank (http://www.ncdc.noaa.gov/paleo/treering.html).

\section{REFERENCES}

Alley, R.B., 2000: The Younger Dryas cold interval as viewed from central Greenland. Quaternary Science Reviews, 19: 213-226.

Guyette, R.P., and Stambaugh, M.C., 2003: The age and density of ancient and modern oak wood in streams and sediments. IAWA, 24: 345-353.

Loader, N.J., Roberston, I., and McCarroll, D., 2003 Comparison of stable carbon isotope ratios in the whole wood, cellulose, and lignin of oak tree-rings. Palaeogeography, Palaeoclimatology, Palaeoecology, 196: 395-407.

Grootes, P.M., Stuiver, M., White, J.W.C., Johnsen, S., and Jouzel, J., 1993: Comparison of oxygen isotope records from the GISP2 and GRIP Greenland ice cores. Nature, 366: 552-554.

Friedrich, M., Lucke, A., Schwalb, A., and Hansich, S., 2004: Late glacial environmental and climatic changes from synchronized terrestrial archives of Central Europe: The Network PROSIMUL. PAGES News, 12(2): 27-29.

\section{Consolidating high- and low-resolution information from different sources into a Northern Hemisphere climate reconstruction}

\section{ShaOpeng Huang}

Department of Geological Sciences, University of Michigan, Ann Arbor, USA; shaopeng@umich.edu

Our understanding of climate history in the pre-industrial era relies principally on climate proxies, each of which has strengths and limitations in representing past climate variability.

A paleoclimate reconstruction from borehole temperature data has its foundation in the theory of thermal diffusion and, as such, is characterized by a progressive inability to resolve climatic excur- sions in the more remote past. But the compensation for the loss of resolution is a better determination of the mean surface temperature in the interval of time for which the details cannot be resolved. Conversely, reconstructions from many traditional proxy approaches offer higher temporal resolution of relative changes but with greater uncertainties in the long-term trends.
It would be desirable to develop a technique to integrate complementary high- and low-resolution climate information preserved in different data sources for a more complete picture of the past climate change. Huang (2004) attempted such an integrated reconstruction of the Northern Hemisphere surface temperature history over the past five centuries through an integrated analysis of the global da- 